\title{
Genetics of a sex-linked recessive red eye color mutant of the tarnished plant bug, Lygus lineolaris
}

\author{
Margaret Louise Allen
}

Biological Control of Pests Research Unit, USDA Agricultural Research Service, Stoneville, USA; meg.allen@ars.usda.gov

Received 5 April 2013; revised 9 May 2013; accepted 23 May 2013

Copyright (C) 2013 Margaret Louise Allen. This is an open access article distributed under the Creative Commons Attribution License, which permits unrestricted use, distribution, and reproduction in any medium, provided the original work is properly cited.

\section{ABSTRACT}

An inbred colony of the tarnished plant bug, Lygus lineolaris (Palisot de Beauvois) (Miridae: Hemiptera), was observed to contain specimens with abnormal traits including red eyes, deformed antennae, and deformed legs. These specimens were isolated and back crossed to create stable phenotypic strains. The only successful strain established was a red eyed strain named Cardinal. The trait was more prevalent and stable in males, suggesting that it could be sex linked. To test the hypothesis that the trait was based on a recessive sex linked allele, classical genetic crosses were performed. The hypothesis was confirmed, and the eye color phenotype was measured and characterized using color analysis software. The trait is similar to other red eyed phenotypes described in this species, but is clearly based on a different mutation since it is sex linked rather than autosomal. The results of crossing experiments also suggest that inbreeding in this species results in substantial fitness cost to laboratory insects.

Keywords: Genetics; Inbreeding; Fitness;

Pigmentation; Ommochromes; Antennae; Spineless

\section{INTRODUCTION}

Variations in the eye color of insects can be found in nature and selected by inbreeding or induced by mutagenesis. Naturally occurring and induced mutations have served as a foundation for progress in both general genetics and in genetic manipulation of insects. A white eye color mutation was found to be linked to sex in Drosophila melanogaster, defining the phenomenon of sexlinkage, and establishing methods in classical genetics [1]. Transplantation studies using D. melanogaster eye disks from multiple eye color strains were vital to the establishment of biochemical pathway genetics [2]. Insect eye colors were later found to be more complex than could be explained by the one-gene-one-enzyme principle, and were shown to be related to transporter pathways [3]. More recently, eye color mutations have been utilized extensively to verify manipulation systems involving genetic transformation $[4,5]$, especially when the eye-specific promoter $3 \mathrm{xP} 3$ is utilized [6].

Eye color mutations have been described in numerous insects other than D. melanogaster. Within the order Diptera, eye color mutations have been described in fruit flies, family Tephritidae [7-9], in blow flies, family Calliphoridae [10-14] and house flies [15-17], in the tsetse fly [18-22], and in many mosquitoes [23-33]. Eye color mutations have also been described in the order Lepidoptera [34-40], in the order Coleoptera [41-43], and in the order Hymenoptera [44-46]. In the order Hemiptera, eye color mutations have been described in kissing bugs (family Reduviidae) [47-51], in the tarnished plant bug, the subject of this paper, family Miridae [52,53], and recently in the brown planthopper, family Delphacidae [54].

The rapid pace of progress in genomics and bioinformatics presents remarkable opportunities for discovery and analysis of insect genes. Efforts to capitalize on this progress will be enhanced by increased focus on basic biological function phenomena in insects that have not yet been developed as model organisms. Naturally occurring strains with genetically defined visible markers will once again serve as valuable resources to scientific progress. A red-eyed strain, established through inbreeding of Lygus lineolaris, was reported previously [53]. A similar strain, established from a wild male specimen collected in the field in Arkansas was reported more recently [52]. Through genetic analysis, the eye color allele in these naturally occurring strains were characterized as autosomal recessive. 
As part of an effort to perform in vivo genetic manipulations on L. lineolaris, a laboratory strain was established in quarantine and inbred for $5+$ years. This strain was examined regularly for unusual phenotypes that might indicate mutation. Phenotypes associated with abnormal appendages were observed but could not be reproduced and maintained in the laboratory through normal breeding. However, an eye color mutation was observed and isolated. To verify that this mutant strain was not the same as the ones previously described, reciprocal crosses were undertaken to test the hypothesis that the mutation was sex linked. Additionally, digital image analysis was utilized to characterize the color of the phenotype. To differentiate the phenotype from those previously described, the strain was called Cardinal, with the eye color mutation cardinal. Strains generated by inbreeding could be highly useful in forthcoming genomics projects using this species of pest insect and other arthropods.

\section{MATERIALS AND METHODS}

\subsection{Insects}

A wild-type colony was maintained without introgression for 5+ years in the Stoneville Research Quarantine Facility (SRQF) in Mississippi. Insect stocks were kept in an environmental chamber (Percival Scientific, Inc. Perry, IA) set for 16:8 (L:D) h lighting regime with $25^{\circ} \mathrm{C}$ daytime and $19^{\circ} \mathrm{C}$ nighttime temperature and $55 \% \mathrm{RH}$. Insects were provided a standardized diet and oviposition system based on NI diet and 4\% gelcarin oviposition substrate [55].

\subsection{Classical Genetics}

For first generation matings small groups of virgin insects, two males and four females, were housed in isolation. Second generation insects were grouped in sets of two males and seven females. Insects were sexed in the $5^{\text {th }}$ instar [52]. Eggs were collected daily. Mature eggs were separated from oviposition substrate and kept on moist filter paper for observation until hatch, then transferred to $100 \mathrm{~mm}$ by $15 \mathrm{~mm}$ Petri dishes for rearing to the adult stage. Nymphs were provisioned with fresh red clover leaves as dietary supplement and refugia.

\subsection{Imaging}

Images of living specimens were collected using a stereoscopic zoom microscope (Nikon SMZ1500) and Nikon digital camera (DMX 1200). Images used to analyze the eye color were cropped to include only eyes and converted to .jpg files then analyzed using RGB software [56]. Each image was analyzed three times using different portions of the eye image for analysis. The means of these samples were then used to generate color match indicators for illustrations.

\subsection{Statistical Analyses}

Egg production data were analyzed using the mixed procedure SAS Enterprise Guide v. 4.2 (SAS 2006). Phenotype and sex ratio data were analyzed for goodness of fit to Mendelian ratios using the Chi-Square test [57].

\section{RESULTS}

After inbreeding a culture of L. lineolaris without introgression for overlapping generations of roughly 60 days for four years (approximately 24 generations), a red eyed individual was identified in a colony cage. For the next two years backcrossing and inspection of the parent colony for additional red eyed stock eventually produced a homozygous strain of red eyed specimens (Figure 1). When the first red-eyed individuals were identified they were invariably male, and were paired with wild type females from the inbred source colony. When back crosses of the offspring were obtained, male red eyed individuals were found but red-eyed females were rare. Thus the possibility that the eye color was a sex linked phenotype was recognized early on. It took several generations to establish a homozygous colony of red-eyed specimens (Cardinal), and the overall fitness of the strain seemed low, compared to the wild type (empirical observation). As Cardinal strain was becoming established, additional rare phenotypes began to appear regularly in both the wild and Cardinal strains. These phenotypes appeared as shortened and deformed appendages, initially short antennae (Figure 2). These individuals were also backcrossed and crossed with one another, but the phenotype was never reliably reproduced in offspring. The most common deformity other than short antennae found in the inbred colonies was truncation of legs (Figure 3). These deformities sometimes coincided with the cardinal mutation, but also appeared in wild types with no apparent linkage. Because the phenotypes could not be established in permanent culture, no genetic data could be collected.

To test the hypothesis that fecundity was lower in the Cardinal strain, eggs were collected from small pools of individuals of wild type, Cardinal, and reciprocal crosses of the two strains. Egg production is shown in Table 1. While the differences in egg production were not significant in the first five or ten days of the test, by day 15 , and continuing on day 20 , the cumulative egg production data met the threshold $(P<0.05)$ to signify statistically significant difference (Table 1). Differences of least squares means on day 20 showed no significance between homozygous Cardinal $(\mathrm{Ca} \times \mathrm{Ca})$ egg production and homozygous wild type $(\mathrm{W} \times \mathrm{W})$ egg production $(P=$ $0.262, \mathrm{t}=-1.24$, df $=6$ ), and also no significant differ- 


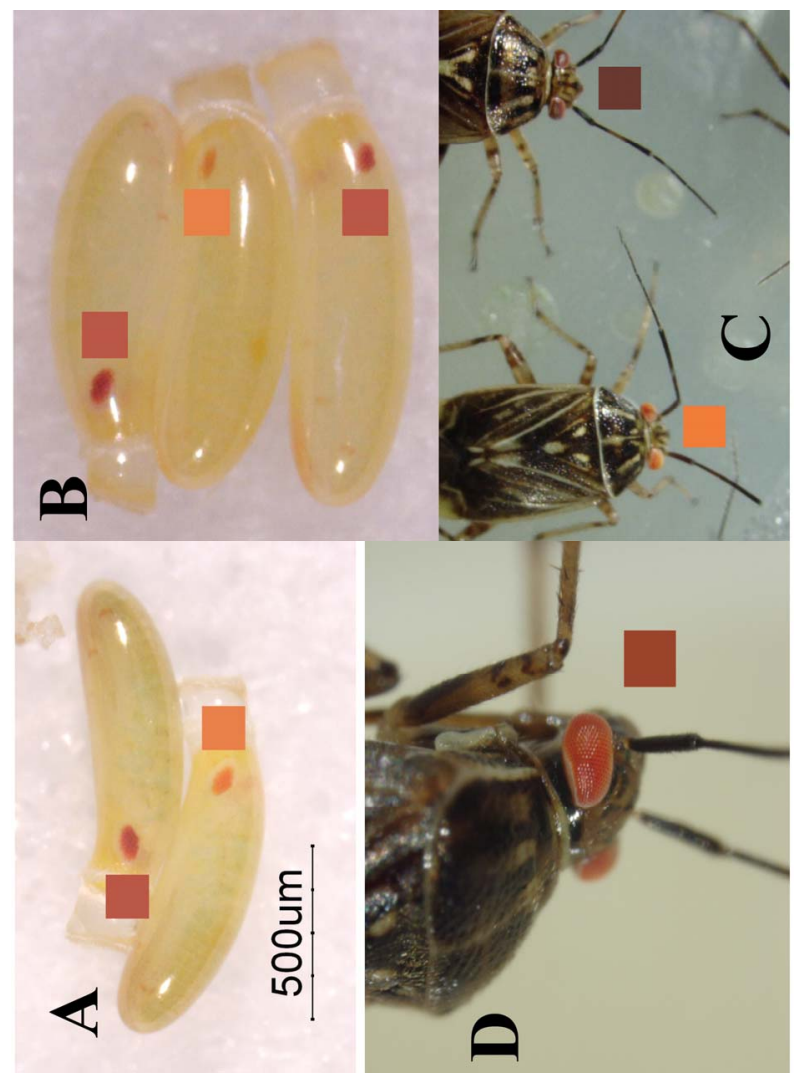

Figure 1. Eye colors of inbred strains of Lygus lineolaris (Palisot de Beauvois) (Hemiptera: Miridae) with square color match indicator boxes. (A) Eggs produced by homozygous insects: normal eye color above, cardinal eye color below; (B) Eggs produced by crossing phenotypes: upper, normal eye color; middle, cardinal eye color from crimson female parent; lower, heterozygous (normal) eye color from crimson female parent; (C) Young adult eye color comparison: left, cardinal; right, normal (wild type); (D) Eye color of an older male (30+ days post adult eclosion/ecdysis).

ence between $\mathrm{Ca} \times \mathrm{Ca}$ and wild type male crossed with Cardinal female $(\mathrm{W} \times \mathrm{Ca})(P=0.291, \mathrm{t}=1.16, \mathrm{df}=6)$ nor between the $\mathrm{W} \times \mathrm{W}$ and $\mathrm{W} \times \mathrm{Ca}(P=0.054, \mathrm{t}=$ $-2.40, \mathrm{df}=6$ ). Additionally, the egg production of reciprocal crosses $(\mathrm{W} \times \mathrm{Ca} / \mathrm{Ca} \times \mathrm{W})$ did not differ from one another $(P=0.099, \mathrm{t}=-1.95, \mathrm{df}=6)$. However, the $\mathrm{Ca} \mathrm{x}$ $\mathrm{W}$ cross produced significantly lower quantities of eggs when compared to homozygous crosses $\mathrm{W} \times \mathrm{W}(P=$ $0.0048, \mathrm{t}=-4.35, \mathrm{df}=6)$ and $\mathrm{Ca} \times \mathrm{Ca}(P=0.021, \mathrm{t}=$ $3.11, \mathrm{df}=6)$.

To test the hypothesis that the phenotype was sex linked, crosses of the Cardinal and wild type strains were evaluated, and yielded the expected ratios of offspring in the first generation for a recessive sex-linked mutation (Table 2A). All offspring of a male Ca parent were wild type, while all male offspring from a female Ca parent were red eyed and all female offspring were wild type. Second generation crosses of heterozygous females from both first generation crosses also yielded expected ratios
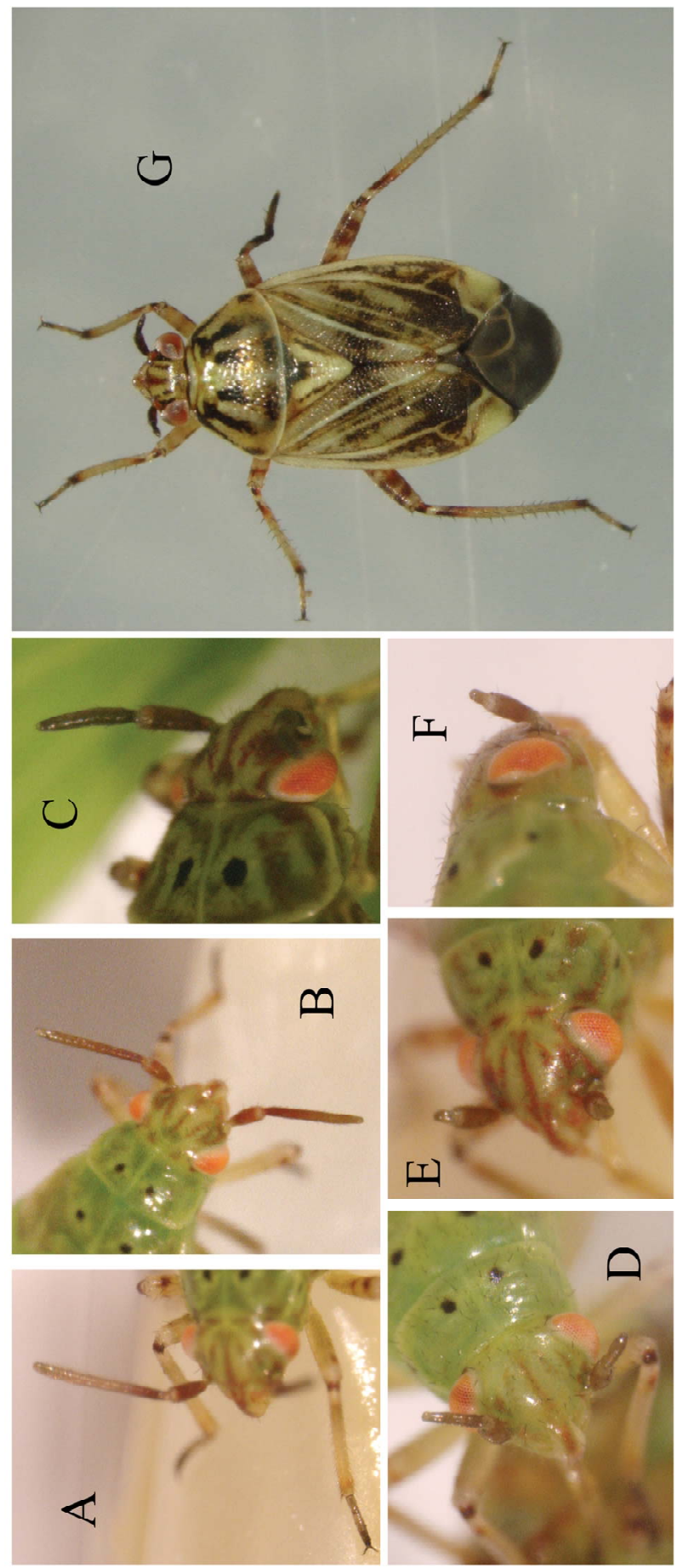

Figure 2. Inbred specimens of Lygus lineolaris that display deformed antennae. (A)-(F) nymphs; (G) adult. Note that the right middle leg of this specimen is also defective, tibia is shortened and tarsal segments are fused.

of offspring (Table 2B). The crosses are illustrated diagrammatically in Figure 4.

Overall survival to the imaginal stage from fertile em bryos was only evaluated in the $F_{1}$ mating pools: from the male Ca parent $55.6 \%$ of wild type offspring survived 
Table 1. Mean cumulative numbers of eggs $( \pm \mathrm{SE})$ produced per female in crosses of inbred wild-type (W) and inbred cardinal-eyed (Ca) specimens of Lygus lineolaris.

\begin{tabular}{|c|c|c|c|c|c|c|c|c|}
\hline \multirow{2}{*}{$\frac{\text { Cross }}{\delta \times q}$} & \multicolumn{8}{|c|}{ Day } \\
\hline & 5 & $\mathrm{n}^{\mathrm{a}}$ & 10 & $\mathrm{n}$ & 15 & $\mathrm{n}$ & 20 & $\mathrm{n}$ \\
\hline $\mathrm{W} \times \mathrm{W}$ & $13.08 \pm 2.39$ & 12 & $25.58 \pm 2.10$ & 12 & $39.25 \pm 2.29$ & 12 & $51.14 \pm 4.29$ & 10 \\
\hline $\mathrm{Ca} \times \mathrm{Ca}$ & $12.33 \pm 2.51$ & 12 & $20.42 \pm 2.92$ & 12 & $31.08 \pm 3.29$ & 12 & $41.25 \pm 3.44$ & 12 \\
\hline $\mathrm{W} \times \mathrm{Ca}$ & $7.33 \pm 4.51$ & 12 & $18.42 \pm 8.42$ & 12 & $24.75 \pm 10.00$ & 12 & $32.00 \pm 11.40$ & 11 \\
\hline $\mathrm{Ca} \times \mathrm{W}$ & $5.33 \pm 1.92$ & 12 & $8.00 \pm 2.74$ & 12 & $12.58 \pm 2.43$ & 12 & $16.42 \pm 1.06$ & 11 \\
\hline $\mathrm{F}$ & 3.17 & & 4.23 & & 7.07 & & 6.83 & \\
\hline$P>F$ & 0.11 & & 0.06 & & 0.02 & & 0.02 & \\
\hline
\end{tabular}

${ }^{\mathrm{a}}$ The degrees of freedom for each comparison was 3.39 .

Table 2. First and second generation crosses of Cardinal eye color strain to parental wild type strain. (A) First generation heterozygous female parents are either combined or identified by the sex of the Cardinal-eyed parent. Second generation combined analysis included with pairwise comparisons of phenotype and male/female ratio. Critical value for all chi-square tests is 3.84 , df $=1$; (B) Second generation crosses, combined data (above) and data analyzed by parent carrying cardinal allele. Critical value for phenotype data is $7.82, \mathrm{df}=3$.

\begin{tabular}{|c|c|c|c|c|c|c|c|c|c|c|c|c|c|c|c|}
\hline \multicolumn{4}{|l|}{ A. } & \multicolumn{6}{|c|}{ adult phenotype } & \multicolumn{6}{|c|}{ adult survival } \\
\hline Cross & egg & otype & $\chi^{2}$ & \multicolumn{2}{|c|}{ wild type } & $\chi^{2}$ & \multicolumn{2}{|c|}{ cardinal } & $\chi^{2}$ & \multicolumn{2}{|c|}{ Totals } & $\chi^{2}$ & \multicolumn{2}{|c|}{ Totals } & $\chi^{2}$ \\
\hline$\delta \times q$ & vild ty & ardinal & & $\hat{\sigma}$ & 우 & & $\hat{\sigma}$ & 우 & & wild type & cardinal & & & 우 & \\
\hline $\mathrm{W} \times \mathrm{W}$ & 580 & 0 & - & 202 & 166 & 0.880 & 0 & 0 & - & 368 & 0 & - & 202 & 166 & 0.880 \\
\hline $\mathrm{Ca} \times \mathrm{Ca}$ & 0 & 537 & - & 0 & 0 & - & 248 & 231 & 0.151 & 0 & 479 & - & 248 & 231 & 0.151 \\
\hline $\mathrm{W} \times \mathrm{Ca}$ & 265 & 228 & 0.694 & 0 & 143 & - & 136 & 0 & - & 143 & 136 & 0.044 & 136 & 143 & 0.044 \\
\hline $\mathrm{Ca} \times \mathrm{W}$ & 337 & 0 & - & 117 & 141 & 0.558 & 0 & 0 & - & 258 & 0 & - & 117 & 141 & 0.558 \\
\hline $\mathrm{Ca} \times \mathrm{F}_{1}$ & 438 & 397 & 2.013 & 103 & 134 & $4.055^{\mathrm{a}}$ & 131 & 125 & 0.141 & 237 & 256 & 0.732 & 234 & 259 & 1.268 \\
\hline
\end{tabular}

B.

$\begin{array}{lll}\text { Cross } & \text { egg phenotype } & \chi^{2} \\ \delta \times q & \text { wild type cardinal }\end{array}$ adult phenotype

\begin{tabular}{|c|c|c|c|c|}
\hline \multicolumn{2}{|c|}{ wild type } & \multicolumn{2}{|c|}{ cardinal } & $\chi^{2}$ \\
\hline$\widehat{\sigma}$ & ㅇ & $\hat{\sigma}$ & q & $(\mathrm{df}=3)$ \\
\hline & 134 & 131 & 125 & 4.777 \\
\hline
\end{tabular}

adult survival

\begin{tabular}{ccccccc}
\multicolumn{2}{c}{ Totals } & $\chi^{2}$ & \multicolumn{2}{c}{ Totals } & $\chi^{2}$ \\
wild type & cardinal & & $\delta$ & $q$ & \\
237 & 256 & 0.732 & 234 & 259 & 1.268
\end{tabular}

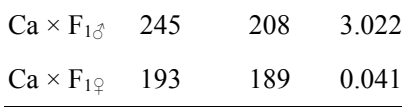

$\begin{array}{lllll}59 & 78 & 75 & 58 & 4.874\end{array}$

137

$\begin{array}{lllll}133 & 0.059 & 134 & 136 & 0.015\end{array}$

$\begin{array}{lllll}44 & 56 & 56 & 67 & 4.749\end{array}$

100

$\begin{array}{lllll}123 & 2.372 & 100 & 123 & 2.372\end{array}$

${ }^{\mathrm{a}}$ Exceeds critical value for chi-square tests, $3.84, \mathrm{df}=1$.

and $64.9 \%$ of cardinal offspring survived; from the female Ca parent $69.5 \%$ of wild type offspring survived and $70.5 \%$ of cardinal offspring survived. No significant difference was detected $(P>0.05$, student t-test, $\mathrm{df}=2)$.

Eye colors of the wild-type embryonic insects corresponded to RGB colors at R $193 \pm 8, \mathrm{G} 88 \pm 7, \mathrm{~B} 70 \pm 10$ while the mutant embryonic eye colors corresponded to RGB colors R $240 \pm 2$, G $130 \pm 7$, B $68 \pm 10$. These colors persisted as developing embryos, nymphs, and through early adult stage. As the adults darken with age, particularly the males, the eyes darken to a more crimson color corresponding to R $161 \pm 7, \mathrm{G} 70 \pm 18$, B $44 \pm 20$.
The fully mature wild-type adult eye corresponds to $\mathrm{R}$ $110 \pm 7$, G $58 \pm 8$, B $48 \pm 6$ (Figure 1).

\section{DISCUSSION}

Standardized laboratory rearing of L. lineolaris is primarily for the purpose of bioassays. The cultures of insects are expected to represent field performance of naturally occurring populations. Thus, colonies are frequently intermixed with new field collected insects in order to maintain colony health and heterozygosity [58]. The laboratory colony in the SRQF differed in that no 


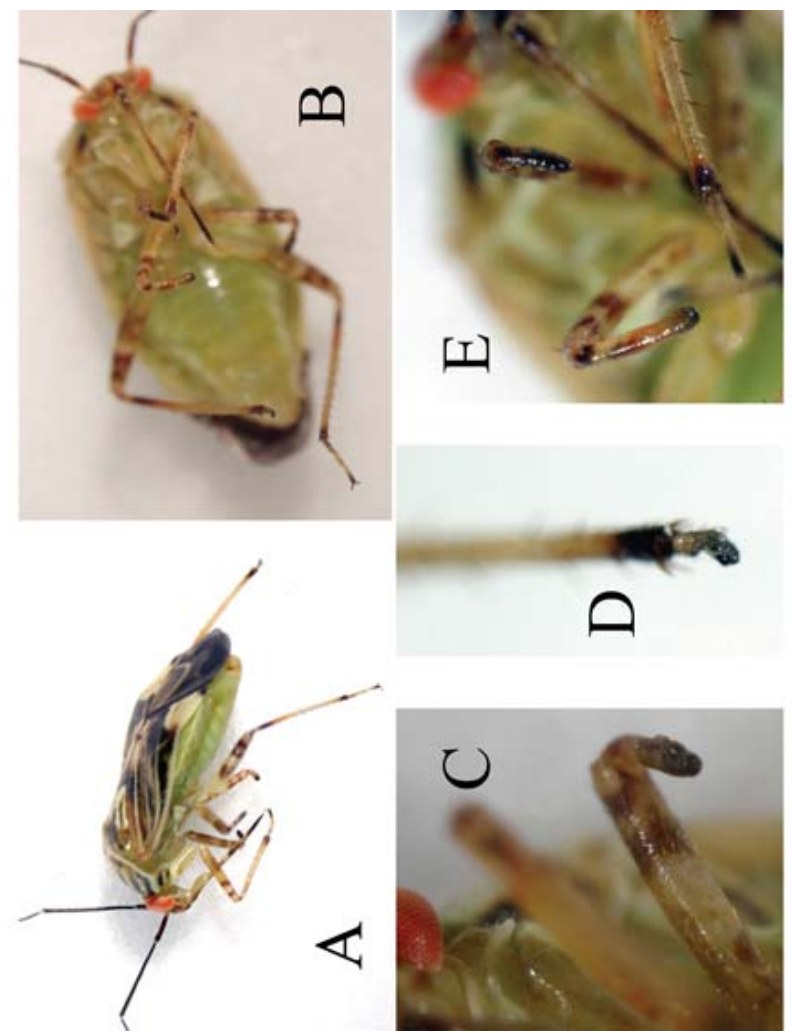

Figure 3. Individual specimen from Cardinal strain with severe leg deformities. Four of six legs have shortened and deformed termini. Tarsal segments appear to be fused. (A) Right lateral view; (B) Ventral view; (C) Left middle leg terminus; (D) Right hind leg; ( E) Right foreleg and middle leg termini.

introgression by field collected insects was allowed. This culture strategy was specifically intended to limit heterozygosity and provide more inbreeding to support genetic analysis and genetic manipulation. Under laboratory inbreeding conditions, spontaneous mutations often are revealed. Novel eye color phenotypes are not uncommon in colonies of insects. Those arising in colonies of D. melanogaster kept by Thomas Morgan and his students formed a foundation for modern genetics.

The truncated appendages observed repeatedly in the inbred colony bear resemblance to defects described in $D$. melanogaster and Tribolium castaneum related to the transcription factor spineless [59-61]. Further careful breeding of similar specimens will be required to determine whether these phenotypes are related. Unfortunately, the specimens we found were delicate and generally infertile, and were discarded after multiple attempts to establish a stable strain failed.

Naturally occurring orange or red eye color phenotypes of Hemiptera have been described [47-50,52-54]. Eye pigments in two species of Hemiptera in the family Reduviidae differ from one another, those from Triatoma infestans Klug being composed primarily of xanthommatin [47], while the eye pigments of Rhodnius prolixus

\section{Autosomal recessive cross:}
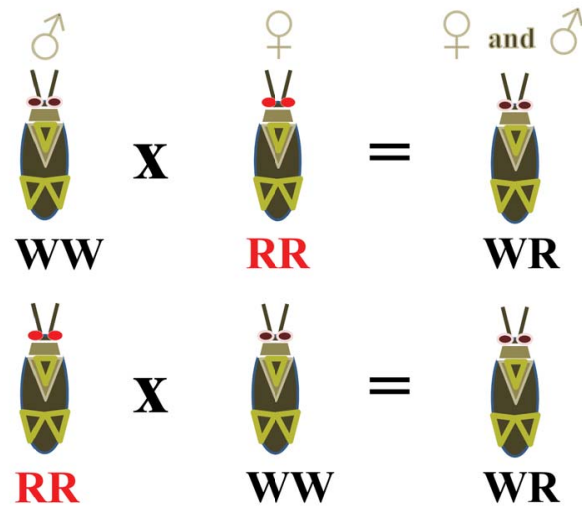

(a)

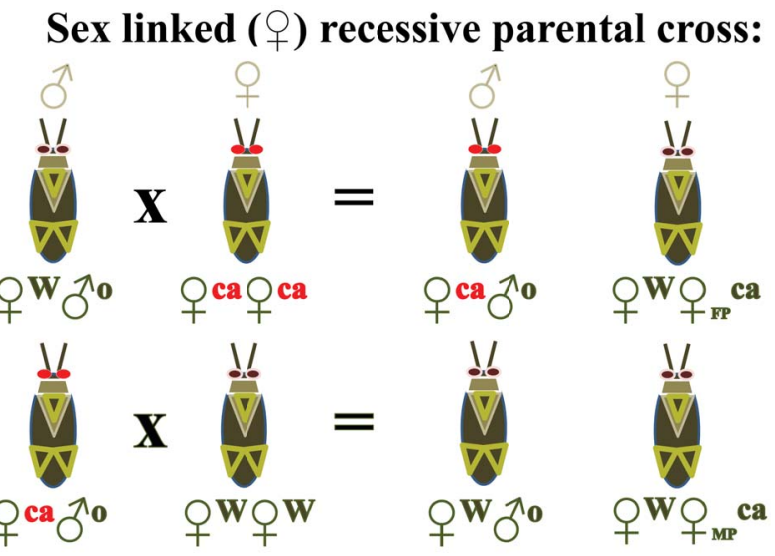

(b)

Sex linked ( $\uparrow)$ recessive $\mathrm{F} 1$ cross:

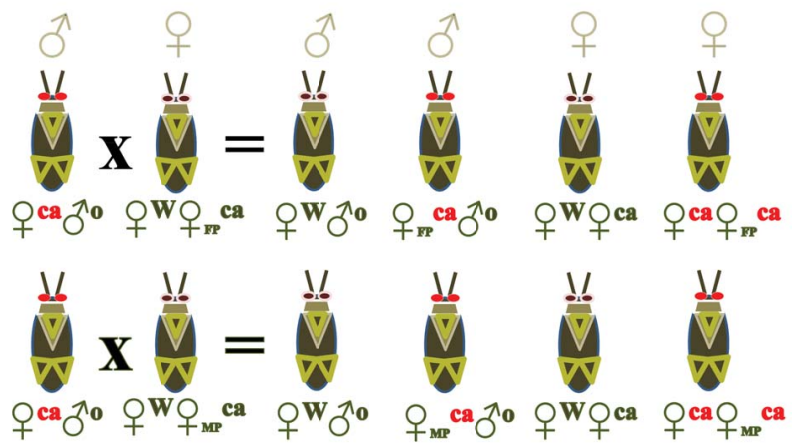

(c)

Figure 4. Diagrams showing expected results from crossing wild type insects with insects carrying an autosomal recessive red eye trait $(\mathrm{R})$ compared with results from crossing wild type insects (WT) with insects carrying a sex linked recessive red eye trait such as cardinal (ca). MP = allele from male parent, FP $=$ allele is from the female parent.

are composed primarily of ommins [62]. The only enzyme identified from $L$. lineolaris from the ommochrome biosynthetic pathway is tryptophan oxygenase (TO) (http://www.ncbi.nlm.nih.gov/nuccore/307634529 and 
http://www.ncbi.nlm.nih.gov/protein/307634530, submitted 10 August 2010, accessed 31 July 2012). This enzyme catalyzes the initial reaction in the conversion of tryptophan to ommochromes, the pigments in insect eyes. The white gene used to define sex linkage by Morgan (1910) was shown to be a membrane pigment transporter gene rather than a pigment synthesis enzyme gene (Sullivan and Sullivan 1975), and this may also be the case in L. lineolaris. The genetic identity of TO has been characterized in D. melanogaster [63], and the red flour beetle Tribolium castaneum [64], and putative homologues with a high similarity at the nucleotide level [65] can be identified in the human body louse Pediculus humanus corporis (XM_002423485.1, accessed from NCBI 16 July 2012) and the mountain pine beetle Dendroctonus ponderosae (BT128347.1, accessed from NCBI 16 July 2012) [66]. While TO may be mutated in either the autosomal or sex-linked phenotypes of red eyed L. lineolaris, any number of other biosynthesis or transport genes may also be responsible.

Both naturally occurring eye color strains of $L$. lineolaris previously identified were characterized as autosomal recessive alleles. The wild collected eye color variant [52] was reported to have little effect on behavior or physiology, although because of the low field prevalence of the phenotype it was implied that there could be a fitness disadvantage, possibly associated with mating disadvantage based on decreased visual ability. The red-eyed " $R$ " strain was kept in culture for $>5$ years, but has since been discarded (G. Snodgrass, personal communication). The eye color mutation identified through inbreeding [53] was not tested for physiological characteristics, but was observed to display no obvious behavioral or developmental differences from wild type. The strain reported here and the progenitor wild type strain both exhibited apparent loss of fitness. The 20 day cumulative egg production reported for the wild caught red strain was over $120 \mathrm{eggs} / \mathrm{female}$, while the specimens reported here produced less than half that in every cross (Table 1). The loss of fecundity is most distinct in the fecundity of the $\mathrm{Ca} \times \mathrm{W}$ cross. The reason for this loss of fecundity is not known. Interestingly, the total number of male vs. female wild type offspring produced by the $\mathrm{Ca}$ $\times F 1$ crosses exceeded the critical value for the expected $\mathrm{m} / \mathrm{f}$ ratio (Table $2 \mathrm{~A}$ ), while the overall phenotype distribution fit the expected results (Table 2B). Inbreeding depression is an accepted phenomenon, relevant to evolution, conservation, and agriculture. Intentional inbreeding is also expected to play a vital and dominant role in future molecular genetics and functional genomic research [67].

If genetic manipulation technology improves to a point at which sex-specific applications such as the sterile insect technique (SIT) can be applied to insects in the order
Hemiptera, identification of sex-specific genes and gene regulation will become critical to project success. Visible markers that can be induced by inbreeding or other methods of mutagenesis will facilitate progress towards these applications, and towards a better understanding of the genetics of these important pest insects.

\section{ACKNOWLEDGEMENTS}

The author extends appreciation to the laboratory technicians who provided assistance and support in completing this work, Fannie M. Byrd, and especially to Catherine L. Smith who performed a vital role in setting up experiments and collecting data. Thanks go to Dr. Xixuan Jin, Dr. William B. Walker III, and Dr. William Rodney Cooper for reviewing a previous version of this manuscript and providing helpful suggestions. The United States Government has the right to retain a non-exclusive, royalty-free license in and to any copyright of this article. This article reports the results of research only. Mention of a commercial or proprietary product does not constitute an endorsement of the product by the United States Department of Agriculture. USDA is an equal opportunity provider and employer.

\section{REFERENCES}

[1] Morgan, T.H. (1910) Sex limited inheritance in Drosophila. Science, 32, 120-122.

doi:10.1126/science.32.812.120

[2] Ephrussi, B. and Beadle, G.W. (1937) Development of eye colors in Drosophila: production and release of $c n$ substance by the eyes of different eye color mutants. $\mathrm{Ge}$ netics, 22, 479-783.

[3] Sullivan, D.T. and Sullivan, M.C. (1975) Transport defects as the physiological basis for eye color mutants of Drosophila melanogaster. Biochemical Genetics, 13, 603613. doi:10.1007/BF00484918

[4] Fridell, Y.W. and Searles, L.L. (1991) Vermilion as a small selectable marker gene for Drosophila transformation. Nucleic Acids Research, 19, 5082. doi:10.1093/nar/19.18.5082

[5] Zwiebel, L.J., Saccone, G., Zacharopoulou, A., Besansky, N.J., Favia, G., Collins, F.H., Louis, C. and Kafatos, F.C. (1995) The white gene of Ceratitis capitata: A phenotypic marker for germline transformation. Science, 270, 20052008. doi:10.1126/science.270.5244.2005

[6] Horn, C., Jaunich, B. and Wimmer, E.A. (2000) Highly sensitive, fluorescent transformation marker for Drosophila transgenesis. Developmental Genes and Evololution, 210, 623-629. doi:10.1007/s004270000111

[7] Yamada, S.M. and Selivon, D. (2001) Rose, an eye color mutation in a species of the Anastrepha fraterculus complex (Diptera: Tephritidae). Annals of the Entomological Society of America, 94, 592-595.

doi:10.1603/0013-8746(2001)094[0592:RAECMI]2.0.C $\mathrm{O} ; 2$

[8] McCombs, S.D. and Saul, S.H. (1989) Genetic studies of the oriental fruit fly, Dacus dorsalis (Diptera: Tephritidae): the first eye color mutant. Annals of the Entomo- 
logical Society of America, 82, 114-115.

[9] Saul, S.H. (1982) Rosy-like mutant of the mediterranean fruit fly, Ceratitis capitata (Diptera: Tephritidae), and Its potential for use in a genetic sexing program. Annals of the Entomological Society of America, 75, 480-483.

[10] Ullerich, F. (1996) Inheritance patterns of new genetic markers and occurrence of spontaneous mosaicism in the monogenic blowfly Chrysomya rufifacies (Diptera: Calliphoridae). Molecular and General Genetics, 253, 232241. doi:10.1007/s004380050317

[11] Taylor, D.B. (1989) Genetics of screwworm: New genetic markers and preliminary linkage map. Journal of Heredity, 80, 425-432.

[12] Gribakin, F.G. and Ukhanov, K. (1993) Light scattering in the eye of the blowfly chalky mutant: The effect on spectral sensitivity of photoreceptors R1-6. Vision Research, 33, 1185-1191. doi:10.1016/0042-6989(93)90207-D

[13] Summers, K.M. and Howells, A.J. (1980) Functions of the white and topaz loci of Lucilia cuprina in the production of the eye pigment xanthommatin. Biochemical Genetics, 18, 643-653. doi:10.1007/BF00484582

[14] Ullerich, F.H. and Langer, H. (1974) Lemon-Another eye colour mutant in the blowfly Calliphora erythrocephala. Molecular and General Genetics, 128, 273-276. doi:10.1007/BF00267116

[15] Hiroyoshi, T. (1960) Some new mutants and linkage groups of the house fly. Journal of Economic Entomology, 53, 985-990.

[16] Kung, K., Kao, C.Y. and Chei, K.T. (1963) Some biological and inherited characters of a mutant white-eyed strain of housefly and its use in bioassay. Acta Entomologica Sinica, 12, 262-267.

[17] Wagoner, D.E. (1969) The ruby eye-color mutant in the house fly, Musca domestica L. A case of duplicate genes. Genetics, 62, 103-113.

[18] Challoner, C.M. and Gooding, R.H. (1997) A white eye color mutant in the tsetse fly Glossina morsitans submotsitans Newstead (Diptera: Glossinidae). Genome, 40, 165169. doi:10.1139/g97-023

[19] Distelmans, W., Makumyaviri, A.M., D'Haeseleer, F., Claes, Y., Le Ray, D. and Gooding, R.H. (1985) Influence of the salmon mutant of Glossina morsitans morsitans on the susceptibility to infection with Trypanosoma congolense. Acta Tropicalis, 42, 143-148.

[20] Gooding, R.H. (1979) Genetics of Glossina morsitans morsitans (Diptera: Glossinidae). III. Salmon, a sex-linked, maternally influenced, semi-lethal eye color mutant. $\mathrm{Ca}$ nadian Entomologist, 111, 557-560. doi:10.4039/Ent111557-5

[21] Gooding, R.H. and Rolseth, B.M. (1995) Genetics of Glossina palpalis palpalis: Designation of linkage groups and the mapping of eight biochemical and visible marker genes. Genome, 38, 833-837. doi:10.1139/g95-109

[22] Rawlings, P. (1985) A sex-linked, recessive, non-deleterious eye-colour mutant in Glossina morsitans centralis. Entomologia Experimentalis et Applicata, 39, 211-212. doi:10.1111/j.1570-7458.1985.tb03565.x

[23] Akhtar, K. and Sakai, R.K. (1985) Genetic analysis of three new eye colour mutations in the mosquito, Anopheles stephensi. Annals of Tropical Medicine and Parasitology, 79, 449-455.

[24] Asman, S.M. (1977) Two sex-linked mutations in Culex tarsalis. Journal of Heredity, 68, 195-197.

[25] Benedict, M.Q., Besansky, N.J., Chang, H., Mukabayire, O. and Collins, F.H. (1996) Mutations in the Anopheles gambiae pink-eye and white genes define distinct, tightly linked eye-color loci. Journal of Heredity, 87, 48-53. doi:10.1093/oxfordjournals.jhered.a022952

[26] Bhalla, S.C., Santos, J.M. and De, F.B. (1975) Genetics of eye-gap and maroon-eye mutants in the mosquito. Journal of Heredity, 66, 349-352.

[27] Ouda, N.A. and Wood, R.J. (1983) Inheritance of browneye and colourless-eye in the mosquito Aedes aegypti. Annals of Tropical Medicine and Parasitology, 77, 211218.

[28] Rasgon, J.L. and Scott, T.W. (2004) Crimson: A novel sex-linked eye color mutant of Culex pipiens L. (Diptera: Culicidae). Journal of Medical Entomology, 41, 385-391. doi:10.1603/0022-2585-41.3.385

[29] Rathor, H.R., Rashid, S. and Toqir, G. (1983) Genetic analysis of a new sex-linked mutant "chestnut eye" an allele of the white eye locus in the malaria vector Anopheles stephensi. Mosquito News, 43, 209-212.

[30] Tadano, T. and Kanda, T. (1975) A new mutant red eye in Aedes riversi. Medical Entomology and Zoology, 27, 201202.

[31] Tadano, T. (1977) Genetics of three new mutants, strawcolored larva, ruby eye and pigmented pupa, in Aedes (Finlaya) togoi (Diptera: Culicidae). Journal of Medical Entomology, 14, 33-37.

[32] Wade, J.O. (1977) The genetics of white eye a sex linked mutant of Aedes cooki. Annals of Tropical Medicine and Parasitology, 71, 483-486.

[33] Adak, T., Wattal, S., Kaur, S. and Sharma, V.P. (1999) Genetics of creamish white, an eye color mutant in Anopheles stephensi. Journal of Heredity, 90, 573-574. doi:10.1093/jhered/90.5.573

[34] Bartlett, A.C. (1979) Genetics of the pink bollworm: sooty body and purple eye. Annals of the Entomological Society of America, 72, 256-259.

[35] Beeman, R.W. (1983) Linkage analysis of genes affecting scale color, eye color, and resistance to malathion in the Indianmeal moth. Journal of Heredity, 74, 301-302.

[36] Al-Hakkak, Z.S., Murad, A.M. and Hussain, A.F. (1985) Orange-eye: A sex-linked recessive mutation in Ephestia cautella (Walker) (Lepidoptera: Pyralidae). Journal of Stored Products Research, 21, 69-71. doi:10.1016/0022-474X(85)90023-2

[37] Brown, T.M., Cho, S.Y., Evans, C.L., Park, S., Pimprale, S.S. and Bryson, P.K. (2001) A single gene (yes) controls pigmentation of eyes and scales in Heliothis virescens. Journal of Insect Science, 1, 1. http://www.insectscience.org/1.1/

[38] Abraham, E.G., Sezutsu, H., Kanda, T., Sugasaki, T., Shimada, T. and Tamura, T. (2000) Identification and characterisation of a silkworm $\mathrm{ABC}$ transporter gene ho- 
mologous to Drosophila white. Molecular and General Genetics, 264, 11-19. doi:10.1007/s004380000283

[39] van den Abbeele, J. and D'Haeseleer, F. (1989) A new eye-colour mutant, brick, in the tsetse fly Glossina palpalis palpalis. Entomologia Experimentalis et Applicata, 52, 257-259. doi:10.1111/j.1570-7458.1989.tb01275.x

[40] Bartlett, A.C. and Lewis, L.J. (1978) Genetics of the pink bollworm: 1 rust, orange, and garnet eye colors. Annals of the Entomological Society of America, 71, 813-816.

[41] Dewees, A.A. and Bell, A.E. (1967) Close linkage of eye color genes in Tribolium castaneum. Genetics, 56, 633640.

[42] Sokoloff, A., Lasley, E.L. and Shrode, R.R. (1960) Linkage studies in Tribolium castaneum Herbst. II . "Pygmy," "red" and "spotted" and their relationships to the sexlinked ma and pd genes. Canadian Journal of Genetics and Cytology, 2, 142-149.

[43] Villavaso, E.J., Wilson, N.M. and Simmons, L.A. (1990) Lavender eye a recessive sex-linked mutant of boll weevil (Coleoptera: Curculionidae) and its map distance from the recessive sex-linked mutant dark scale. Annals of the Entomological Society of America, 83, 230-233.

[44] Laidlaw, H.H., Banby, M.A. and Tucker, K.W. (1964) Five new eye-color mutants in the honey bee. Journal of Heredity, 55, 207-210.

[45] Laidlaw, H.H. and Tucker, K.W. (1965) Umber eyecolor-A new mutant in honey bees. Journal of Heredity, 56, 271-272.

[46] Lee, J.M., Hashino, Y., Hatakayama, M., Oishi, K. and Naito, T. (1998) Egg deposition behavior in the haplodiploid sawfly Athalia rosae ruficornis Jakovlev (Hymenoptera: Symphyta: Tenthredinidae). Journal of Insect Behavior, 11, 419-428. doi:10.1023/A: 1020958831972

[47] Moraes, A.S., Pimentel, E.R., Rodrigues, V.L.C.C. and Mello, M.L.S. (2005) Eye pigments of the blood-sucking insect, Triatoma infestans klug (Hemiptera, Reduviidae). Brazilian Journal of Biology, 65, 477-481. doi:10.1590/S1519-69842005000300013

[48] Noé, C. and Silva, C. (1949) A new variety of Triatoma infestans. Boletin de Informaciones Parasitarias Chilenas, 4, 4-5.

[49] Pires, H.H.R., Abrão, D.O., Machado, E.M.d.M., Schofield, C.J. and Diotaiuti, L. (2002) Eye colour as a genetic marker for fertility and fecundity of Triatoma infestans (Klug, 1834) Hemiptera, Reduviidae, Triatominae. Memórias do Instituto Oswaldo Cruz, 97, 675-678. doi:10.1590/S0074-02762002000500016

[50] Rosabal, R. and Trejos, A. (1966) On a mutation of eye color in Rhodnius prolixus [Engl. summ.]. Revista de Biologia Tropical, 14, 99-103.

[51] Wygodzinsky, P. and Briones, S. (1954) Nota sombre mutaciones del color del ojo en Triatoma (Klug). Anales del Instituto de Medicina Regional De la Universidad Nacional de Tucuman, 4, 115-118.

[52] Snodgrass, G.L. (2002) Characteristics of a red-eye nutant of the tarnished plant bug (Heteroptera: Miridae). Annals of the Entomological Society of America, 95, 366-369. doi:10.1603/0013-8746(2002)095[0366:COAREM]2.0.C
$\mathrm{O} ; 2$

[53] Slaymaker, P.H. and Tugwell, N.P. (1984) Inheritance of red eye color in Lygus lineolaris (Palisot de Beauvois) (Hemiptera: Miridae) an abnormal trait. Journal of the Kansas Entomological Society, 57, 343-344.

[54] Seo, B.Y., Jung, J.K. and Kim, Y. (2011) An orange-eye mutant of the brown planthopper, Nilaparvata lugens (Hemiptera: Delphacidae). Journal of Asia-Pacific Entomology, 14, 469-472. doi:10.1016/j.aspen.2011.06.005

[55] Cohen, A.C. (2000) New oligidic production diet for Lygus hesperus Knight and L. lineolaris (Palisot de Beauvois). Journal of Entomological Science, 35, 301310.

[56] Byers, J.A. (2006) Analysis of insect and plant colors in digital images using Java software on the Internet. Annals of the Entomological Society of America, 99, 865-874. doi:10.1603/0013-8746(2006)99[865:AOIAPC]2.0.CO;2

[57] Zar, J.H. (1996) Biostatistical analysis. Prentice-Hall, Inc., New York.

[58] Abel, C.A., Snodgrass, G.L., Jackson, R. and Allen, C. (2010) Oviposition and development of the tarnished plant bug (Heteroptera: Miridae) on field maize. Environmental Entomology, 39, 1085-1091. doi:10.1603/EN10010

[59] Emmons, R.B., Duncan, D. and Duncan, I. (2007) Regulation of the Drosophila distal antennal determinant spineless. Developmental Biology, 302, 412-426. doi:10.1016/j.ydbio.2006.09.044

[60] Emmons, R.B., Duncan, D., Estes, P.A., Kiefel, P., Mosher, J.T., Sonnenfeld, M., Ward, M.P., Duncan, I. and Crews, S.T. (1999) The spineless-aristapedia and tango bHLH-PAS proteins interact to control antennal and tarsal development in Drosophila. Development, 126, 3937 3945 .

[61] Shippy, T.D., Yeager, S.J. and Denell, R.E. (2009) The Tribolium spineless ortholog specifies both larval and adult antennal identity. Development Genes and Evolution, 219, 45-51. doi:10.1007/s00427-008-0261-9

[62] Linzen, B. (1974) The tryptophan-ommochrome pathway in insects. In: Beament, J.W. and Treherne, J.E., Eds., Advances in Insect Physiology 10, Academic Press, Waltham, pp. 117-246.

[63] Searles, L.L. and Voelker, R.A. (1986) Molecular characterization of the Drosophila vermilion locus and its suppressible alleles. Proceedings of the National Academy of Sciences USA, 83, 404-408. doi:10.1073/pnas.83.2.404

[64] Lorenzen, M.D., Brown, S.J., Denell, R.E. and Beeman, R.W. (2002) Cloning and characterization of the Tribolium castaneum eye-color genes encoding tryptophan oxygenase and kynurenine 3-monooxygenase. Genetics, 160, 225-234.

[65] Altschul, S.F., Madden, T.L., Schaffer, A.A., Zhang, J., Zhang, Z., Miller, W. and Lipman, D.J. (1997) Gapped BLAST and PSI-BLAST: A new generation of protein database search programs. Nucleic Acids Research, 25 3389-3402. doi:10.1093/nar/25.17.3389

[66] Keeling, C.I., Henderson, H., Li, M., Yuen, M., Clark, E.L., Fraser, J.D., Huber, D.P., Liao, N.Y., Docking, T.R., 
Birol, I., Chan, S.K., Taylor, G.A., Palmquist, D., Jones, S.J. and Bohlmann, J. (2012) Transcriptome and fulllength cDNA resources for the mountain pine beetle, Dendroctonus ponderosae Hopkins, a major insect pest of pine forests. Insect Biochemistry and Molecular Biology, 42, 525-536. doi:10.1016/j.ibmb.2012.03.010
[67] Ayroles, J.F., Hughes, K.A., Rowe, K.C., Reedy, M.M., Rodriguez-Zas, S.L., Drnevich, J.M., Caceres, C.E. and Paige, K.N. (2009) A genomewide assessment of inbreeding depression: Gene number, function, and mode of action. Conservation Biology, 23, 920-930.

doi:10.1111/j.1523-1739.2009.01186.x 